\title{
EDTA: THE CHELATING AGENT UNDER ENVIRONMENTAL SCRUTINY
}

\author{
Claudia Oviedo and Jaime Rodríguez*
}

Renewable Resources Laboratory, Universidad de Concepción Casilla 160-C, Concepción, Chile

Recebido em 6/3/03; aceito em 28/4/03

\begin{abstract}
EDTA: THE CHELATING AGENT UNDER ENVIRONMENTAL SCRUTINY. The chelating agent EDTA (ethylenediaminetetraacetic acid) is a compound of massive use world wide with household and industrial applications, being one of the anthropogenic compounds with highest concentrations in inland European waters. In this review, the applications of EDTA and its behavior once it has been released into the environment are described. At a laboratory scale, degradation of EDTA has been achieved; however, in natural environments studies detect poor biodegradability. It is concluded that EDTA behaves as a persistent substance in the environment and that its contribution to heavy metals bioavailability and remobilization processes in the environment is a major concern
\end{abstract}

Keywords: EDTA; environment; degradation.

\section{CONSUMPTION AND APPLICATION OF EDTA}

Metal ions cause detrimental effects in several industrial processes and in the formulation of many products. Earth alkaline divalent cations such $\mathrm{Ca}$ (II), $\mathrm{Mg}$ (II) and $\mathrm{Ba}$ (II) form insoluble precipitates with carbonates, sulfates and phosphates. In addition, the presence of transition metal ions such as those of copper, iron, zinc and manganese may trigger chemical processes of corrosion, catalytic degradation, polymerization inhibition, redox reactivity and changes in the coloring of products ${ }^{1}$. In industrial processes these metal cations may come from the process waters, raw materials, equipment erosion and corrosion. They may also be added as a specific metal species, but they may later suffer undesired alterations due to changes in concentration, $\mathrm{pH}$, oxidation, or reactions with other ingredients during the process. EDTA is a chelate ligand with a high affinity constant to form metal-EDTA complexes, being deliberately added to sequester metal ions .

EDTA was patented in Germany in 1935 by F. Munz. The molecule is a substituted diamine (Figure 1) usually marketed as its sodium salts. It is a powerful complexing agent of metals and a highly stable molecule, offering a considerable versatility in industrial and household uses $^{2}$ (Table 1). Since it is applied predominantly in aqueous medium, it is released into the environment through wastewaters. Its presence in soils may be due to agrochemical application or to the disposal of products containing EDTA in garbage reservoirs. It is highly unlikely to find the compound in the air because of the impossibility of volatilization from waters or soils. Although this could occur for example, in the event of aerial application of the compound (e.g.: agrochemical application).

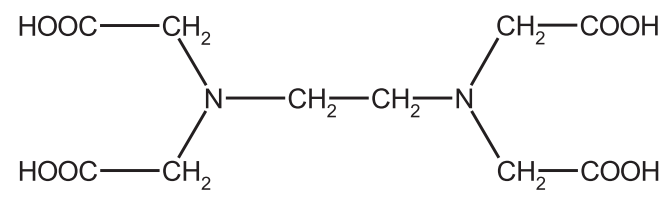

Figure 1. Molecular structure of EDTA

*e-mail: jrodrig@udec.cl
Table 1. Industrial and household uses of EDTA and its ligands (as percentages of the world market) ${ }^{\mathrm{a}}$

\begin{tabular}{lc}
\hline Use & $\%$ of world market \\
\hline Detergents & 33 \\
Water treatment & 18 \\
Pulp and Paper Industry & 13 \\
Photography & 5 \\
Metal Cleaning & 5 \\
Cosmetics, foodstuffs, pharmaceuticals & 5 \\
Agrochemicals & 4 \\
Textile Industry & 4 \\
Printing inks & 3 \\
Concrete admixtures & 2 \\
Miscellaneous & 12
\end{tabular}

${ }^{a}$ Modified from ref. 2

The product is marketed worldwide under 30 different trademarks and its use in the world is massive and increasing ${ }^{3}$. In 1992, the annual consumption in Europe was in the order of 26,000 tons ${ }^{4}$ and in 1997 this value had increased to 32,550 tons $^{5}$. Given the magnitude of this use, EDTA is one of the organic pollutants found in highest proportions in surface waters in central Europe ${ }^{6,7}$.

As it can be seen in Table 1, the main application of EDTA is in cleaning products and detergents based on perborates as stabilizers and, in some countries, as an alternative to phosphates in detergent formulation. In 1990, a consumption of 25,000 tons was estimated in Germany in laundry detergents ${ }^{8}$.

The use of the chelate in the pulp and paper industries is of considerable magnitude (13\% of the world market). This proportion could increase progressively if the pulp and paper industry favors pulp producing processes in which bleaching is free from chlorine containing compounds or TCF pulp (totally chlorine free). EDTA or DTPA (diethylenetriaminepentaacetic acid) are used to avoid the undesirable effects of ferric, cupric and manganic ions in bleaching. In the bleaching stage with hydrogen peroxide or ozone, those metals promote the formation of hydroxyl radical $(\mathrm{OH} \cdot)$ which destroys the cellulose fiber and decompose the bleaching agents. In some cases, 
chelators are also used during the oxygen delignification stage. It is illustrative to point out the Scandinavian situation, where a rapid increase in the consumption of EDTA and DTPA has been observed, associated with the production of TCF pulp. It should be born in mind that the Scandinavian pulp and paper industry alone used 23,000 tons of chelating agents during $1998^{3}$ which is close to the 26,000 tons of the total consumption of EDTA in Western Europe in $1992^{4}$.

\section{ECOTOXICOLOGICAL RISKS OF EDTA}

There is increasing concern about the direct or indirect potential effects of the presence of EDTA in the environment. Numerous field studies have shown that complexation with EDTA may mobilize contaminant metal ions. EDTA may avoid the precipitation of heavy metals in solution or, on the contrary, cause a dissolution effect of heavy metals adsorbed in sediments ${ }^{7,9,10}$. Hence, the result is an enhanced mobilization of heavy metals. Attention has also been paid to the fact that EDTA can solubilize radioactive metals and increase their environmental mobility ${ }^{12-14}$.

Another aspect to be considered, is the possible contribution of EDTA in eutrophication water processes. Sillanpää ${ }^{7}$ warns that this phenomenon is relevant, since the molecule contains approximately $10 \%$ of nitrogen that could eventually be available to the aquatic microbiota. EDTA would also have an indirect effect, when it redissolves the calcic and ferric phosphates, releasing phosphorous and thus contributing to an increase in the productivity of the waters. There could also be a larger bioavailability of $\mathrm{Fe}^{+3}$ (essential micronutrient for microalgae) thus stimulating their growth.

Although the isolated molecule does not present a risk of bioaccumulation, the ligand-metal complexes may significantly increase the bioavailability of extremely dangerous heavy metals. In fact, the dissolution and bioavailability of heavy metals are phenomena worth of greater attention. Vassil et al. ${ }^{15}$ studying the role of EDTA in the consumption of lead in a variety of the mustard plant, discovered a concentrating effect of 75 times, which is highly significant if account is taken that it is a potentially dangerous phenomenon in terms of metal biomagnification processes. Enhanced uptake of heavy metals by plants has been extensively studied ${ }^{16-18}$ due to its potential use in heavy metal phytoextraction technologies, but special attention has been paid to their concomitant lixiviation and migration phenomena ${ }^{17}$.

Dufková ${ }^{19}$ studied the interaction of EDTA with photosynthetic organisms and found that EDTA is toxic, since it inhibits cellular division, chlorophyll synthesis and algal biomass production. It is interesting to note that the same concentration of EDTA chelated with micronutrients did not present these toxic effects.

Greman et al. ${ }^{17}$ found strong inhibitory effects of EDTA over plants such as: necrotic lesions on leaves of Chinese cabbage, absence of development of arbuscular mycorrhizae in Red clover plants, and stress on soil microfauna, being soil fungi the most affected community.

Research of the cellular toxicity of chelates indicates, in general, noxious effects normally attributed to the lack of metals essential to various cellular functions. The findings of Hugenschmidt et al. ${ }^{20}$ are particularly interesting. They trace the effects of chronic exposure to low levels of EDTA $(<100 \mu \mathrm{M})$ in cultured cells of rat kidney, resulting in high rates of cellular death. In addition, Gabard ${ }^{21}$ reported inhibition of DNA, RNA and protein synthesis due to the chelation of zinc and manganese in rat liver cells after EDTA-Ca(II) administration.

Regarding to oral human exposure, Fe(III)-EDTA salts are considered safe and used as an iron supplement ${ }^{22}$ source. However, a recent study proposes carbonyl iron as a better fortificant than
NaFeEDTA salts, because it resulted to be less toxic when tested in acute toxicity in young rats ${ }^{23}$. Free EDTA has been shown to produce adverse reproductive and developmental effects in mammals. However, it is considered as a safe substance if used externally; which is relevant considering that EDTA is a common ingredient in cosmetic formulation $^{24}$.

EDTA has antibacterial activity and metal chelation of the ligand reduces this activity ${ }^{25}$. The effect of chelating agents upon gram negative bacteria has been reported. EDTA causes disruption of the outer membrane, since it is capable of removing its calcic and magnesic divalent cations, with the consequent loss of substantial amounts of lipopolysacharide, which in turn, make cells susceptible to the action of many substances such as detergents, proteases, lipases and lysozymes ${ }^{26-28}$. Hennecken et al. $^{4}$ clearly show a total inhibition of a bacterial consortium by free EDTA, these bacteria only manage to degrade EDTA if it is complexed with equimolar quantities of calcium or magnesium ions.

Paradoxically, even though literature provides evidence of the persistence and low natural degradability of the chelate, the study of its toxicity is basically documented for acute toxicity bioassays and there is not sufficient information for the evaluation of chronic toxicity.

Until recently, it used to be postulated that the concentration of free metals in solution was the main factor in the bioavailability and toxicity of metals. It has also been proved that heavy metals complexed with EDTA (and also with humic acids) are biologically available and toxic. This has been demonstrated in the study of Tubbing et al..$^{28}$ with river microalgae in which photosynthesis is inhibited at low concentrations of EDTA chelated with copper (II) (5-10 $\mu \mathrm{M})$ and unchelated EDTA. As stated previously, this is also evident in the work of Vassil et al. ${ }^{15}$.

Acute toxicity bioassays have been used to compare the toxicity of free heavy metals $\left(\mathrm{Hg}^{+2}, \mathrm{Cd}^{+2}, \mathrm{~Pb}^{+2}, \mathrm{Zn}^{+2}, \mathrm{Cu}^{+2}, \mathrm{Fe}^{+3}, \mathrm{Mn}^{+2}\right)$ with the EDTA-complexes, in Photobacterium phosphoreum bacteria ${ }^{29}$ and for the fresh water cladoceran Daphnia magna ${ }^{30}$. These studies show that the formation of the chelate-metal coordination compound, achieves a decrease in the toxicity of free heavy metals. On the contrary Guilhermino et al. ${ }^{31}$ found that $\mathrm{Cd}(\mathrm{II})$-EDTA and $\mathrm{Cu}(\mathrm{II})$ EDTA complexes were more toxic than their respective free metals in acute toxicity test in Daphnia magna.

\section{EDTA IN SURFACE WATERS}

Although there is not enough research describing the behavior of the chelate in surface waters, it can be seen that this is a complex, multivariable and dynamic phenomenon, which makes it difficult to predict fate and to quantify the speed of the processes involved. Some authors warn that the theoretical calculations based on chemical balance are not a useful tool for predicting EDTA speciation in effluents, since the kinetic dimension of the processes of metal interchange cannot be overlooked ${ }^{32,33}$. The influence of the suspended material and the consequent occurrence of adsorption and desorption phenomena on their surface, must be also considered.

The validity of the theoretical approximation is further diminished if account is taken of the fact that EDTA is one of many natural and anthropogenic ligands which can be found in the aquatic medium. Moreover, the geochemical nature of rocks underlying the type of fresh water studied must be taken into consideration, since this will influence the $\mathrm{pH}$ and the provision of metals to the waters.

In natural environments EDTA occurs as metal-EDTA complexes. At present, there is not enough information on the aquatic speciation and on the natural ligands competition phenomena which are crucial for predicting the metal-EDTA complexes environmental 
fate ${ }^{33}$. Table 2, shows some of the ranges of concentration of EDTA found in natural waters. The highest value has been found in England $\left(1120 \mu \mathrm{gL}^{-1}\right)$.

Table 2. EDTA in natural waters ${ }^{b}$

\begin{tabular}{ccc}
\hline $\begin{array}{c}\text { Range of concentration } \\
\left(\mu g L^{-1}\right)\end{array}$ & $\begin{array}{c}\text { Type of fresh } \\
\text { water }\end{array}$ & Location \\
\hline 158 & River & France \\
$14-1120$ & River & England \\
$3.4-22.2$ & River & Germany \\
2.9 & Lake & Germany \\
$9.1-28.0$ & River & Germany \\
900 & River & Jordan \\
$5.0-60$ & River & Germany \\
$2.0-45$ & River & Switzerland \\
$10-80$ & River & Germany \\
$7-104$ & River & Germany \\
0.52 & Lake & Greece \\
5.85 & Sea & Greece \\
$1.6-13.5$ & River & Germany \\
$2.6-29.2$ & Surface & Netherlands \\
$2.0-25$ & River & Germany \\
$1.7-44.0$ & Lake & Finland \\
\hline
\end{tabular}

${ }^{\mathrm{b}}$ Data extracted from refs. 7 and 75

In surface waters, the only significant process of removal of EDTA is the possibility of photolysis by means of the action of sunlight upon the Fe (III)-EDTA complex ${ }^{32,34}$. It could be possible, in theory, to speculate on a continuous photolysis of the complex EDTA-Fe(III) which would entail the massive degradation of the chelate. However, Kari and Giger $^{32}$ point out the factual impossibility of such phenomenon on the basis of the intensity of light and the adsorption phenomena of photostable complexes of EDTA. This is in agreement with its relatively high concentrations that have been found in European continental waters ${ }^{6,7}$.

According to the literature, there may be photolysis under high transparency conditions and in shallow watercourses. In the study of Kari and Giger ${ }^{32}$, performed in natural waters, photodecomposition of the EDTA-Fe(III) complex is reported as the main degradation process.

The studies on the photodegradability of EDTA in the environment should also take into account the cloud cover in the sky and suspended material in the waters, since these are factors that condition the intensity of light received by water ${ }^{32,34}$.

\section{EDTA IN GROUND WATER AND SOIL}

Essentially, the studies of EDTA behavior in soil and ground water attempt to verify metal lixiviation phenomena. The possibility that organic anthropogenic ligands increase the concentration of metals dissolved in subsoil water has been formulated. Nowack et $a l .{ }^{35}$ established that EDTA behaves as a persistent substance in its passage towards ground water and that its speciation varies. Remobilization of metals through the infiltration course of water from a calcarean lithic riverbed towards subsoil water was demonstrated.

The removal of heavy metals in soil by EDTA is known and in fact, it is a proposed technique for washing soil contaminated with heavy metals ${ }^{36-38}$. With respect to the passage of EDTA to ground water, through the soil, it is necessary to mention a mobility study of heavy metals in a landfill by Lo et al. ${ }^{9}$ They establish that the presence of EDTA inhibits the adsorption of heavy metals to the soil, thus inducing their lixiviation.

The mobility of heavy metals in soils is conditioned by numerous factors, among which, $\mathrm{CO}_{2}$ partial pressure, temperature, dissolved organic matter, micro-organisms, identity of the metal(s) and its (their) respective concentration(s), etc. Thus, the way, in which EDTA influences the mobility of metals, is also multivariable and complex ${ }^{39}$.

The possibility of finding EDTA biodegrading activity in ground water and soil would be of interest, since in this substrate photolysis could not constitute a degradation option. However, significant biodegrading activities have not been found. There are only registers of poor and slow performances of microbial consortia in soil and subsoil ${ }^{40-42}$.

\section{EDTA BIODEGRADATION}

EDTA resistance to bacterial biodegradation is widely documented ${ }^{41-44}$. The compound is harmful to gram negative bacteria, causing the destruction of their outer membrane ${ }^{26-28}$.

At laboratory scale, biodegradation by enriched bacterial cultures has been achieved. Nörtemann ${ }^{5}$, suggested catabolic pathways of EDTA in bacteria, this approach considers uncomplexed EDTA entrance to the cell, and shows the loss of an acetyl group as the first step in this intracellular oxidation. However, it has been recently demonstrated that the bacterial strain DSM 9103 (located in the Rhizobium-Agrobacterium branch), degrades EDTA as a sole carbon source and it is able to perform the cellular uptake of the metallic complex EDTA-Ca (II), with intracellular calcium polyphosphates accumulation ${ }^{45}$. The identified bacterial strains with EDTA degrading abilities are all aerobic, gram negative bacteria ${ }^{46}$.

In cases in which degradation of the chelate has been proved, it is necessary to point out that both the metal-chelate speciation and the bacterial species in question, are determining factors in the ability to degrade the compound. Thus, in certain cases there is only the ability to degrade metal-chelate complexes of low stability constant, as for example EDTA-Ca (II) and EDTA-Mg (II) complexes ${ }^{4,45,47}$ and that in other cases, the exact opposite occurs: the EDTA-Fe(III) complex with a high stability constant is degraded ${ }^{13,48,49}$. Furthermore, from the data available for the intracellular catabolism of EDTA, no generalizing pattern with respect to the influence of metal speciation on degradation can be deduced ${ }^{50}$.

Table 3 presents the data of bacterial activities with complete EDTA mineralization and their respective references. Palumbo et al. ${ }^{13}$ found that the bacterial ability to degrade EDTA is rare, since they could not obtain degrading consortia from places polluted with the chelate. The only degradation achieved was with a strain of Agrobacterium $s p$. previously isolated from a nuclear waste disposal facility and of known EDTA degrading activity, and not with other related Agrobacterium strains.

\section{EDTA IN WATER TREATMENT PLANTS}

\section{In drinking water plants}

In drinking water plants, filtering trough activated carbon is useless to remove the chelate (given its hydrophilic character). According to Gilbert and Hoffmann-Glewe ${ }^{51}$, in drinking water producing plants with ozone treatment it is possible to degrade EDTA, the degree of degradation depending on the ozone level.

Attempts have been made to degrade EDTA, in order to produce drinking water, by means of technologies contemplating the use of photochemical oxidation systems like $\mathrm{UV} / \mathrm{H}_{2} \mathrm{O}_{2}$ treatment ${ }^{52,53}$. However, the same authors warn that the required concentration of 
Table 3. Microbial mineralization of EDTA

\begin{tabular}{lccc}
\hline Degrading Microorganism & Tested concentration & Time (days) & Reference \\
\hline Agrobacterium sp. & $35 \mathrm{mM}$ & 3 & 48 \\
Agrobacterium sp. & $35 \mathrm{mM}$ & 2.8 & 5 \\
Activated sludge & $3 \mathrm{mM}$ & $<0.5$ & 76 \\
Bacterial strain DSM 9103 & $1 \mathrm{mM}$ & 3.3 & 45 \\
Bacterial consortia rich in strain BNC ${ }_{1}$ & $1.53 \mathrm{mM}$ & $28-49$ & 77 \\
Soil consortia and agricultural sediment & $4 \mathrm{ug}{ }^{14} \mathrm{C}-\mathrm{EDTA} / \mathrm{g}$ of soil & 115 & 40 \\
Surface and subsurface soil consortia & $0.01 \mathrm{mM}$ & 41 \\
\hline
\end{tabular}

peroxide is such that the residual peroxide exceeds the peroxide concentration allowed by the German standards they also point out that by-products of EDTA degradation can be promoters of microbial re-growth. In order to avoid the potential microbial enrichment, they suggest a later chlorinating phase, but they do foresee the potential danger of the production of highly toxic substances resulting from this step, as well as pointing out that chlorinating might be inefficient, since both glycinate and iminodiacetate (products of EDTA degradation through $\mathrm{UV} / \mathrm{H}_{2} \mathrm{O}_{2}$ treatment) may reduce the disinfecting ability of the chlorinating step since they can be substrates of microbial growth.

\section{In waste water treatment plants}

Most of the reports indicate that biological treatments are not efficient in the degradation of the chelate. Hinck et al. ${ }^{44}$ evaluate EDTA biodegradation in a complete study using four types of different sludge, finding a total absence of EDTA degradation.

The chelate passes unmodified through wastewater treatment plants because of its resistance to biodegradation and scarce adsorbability. Thus, in Swiss sewage treatment plants equipped with both chemical and biological treatment systems, it is found that no significant EDTA elimination is achieved ${ }^{54,55}$. Nirel et al. ${ }^{55}$ found that 10 of 12 domestic sewage treatment plants had EDTA in their effluents. In industrial waste water treatment plants, the chelate generally shows poor biological degradability ${ }^{44,56}$ and presents two additional problems: it affects their efficiency to remove heavy metals and increases the charge of dissolved nitrogen in effluents. Saunamäki ${ }^{56}$, shows EDTA increases the level of nitrogen released by activated sludge of a pulp plant run under TCF processes, which is highly undesirable since this input could increase the receiving water's productivity. The study also reported that activated sludge treatment does not remove the chelate but that, with the addition of aluminum sulfate, a $65 \%$ removal of EDTA was achieved.

Sillanpää ${ }^{57}$, reports a $17 \%$ to $30 \%$ of EDTA reduction, in three plants of activated sludge of finish pulp and paper mills. Using a synthetic TCF cellulose bleaching effluent Mutis et al. ${ }^{58}$ report a maximum of $33 \%$ EDTA removal and 19\% DTPA removal in activated sludge acclimatized to a mixture of EDTA and DTPA. Virtapohja and Alén ${ }^{59}$, reported an increase in the degrading efficiency in activated sludge from pulp and paper effluents, when operating with alkaline $\mathrm{pH}$, in which an average EDTA reduction of $10 \%$ at neutral $\mathrm{pH}$, increases to $50 \%$ at $\mathrm{pH} 8$ to 9 . The greatest degrading efficiencies are reported by Van Ginkel et al. ${ }^{60}$ with an $80 \%$ EDTA degradation at $\mathrm{pH} 8$ and by Kaluza et al. ${ }^{61}$ which reached an $80 \%$ removal in a pulp and paper mill TCF effluent.

The presence of EDTA and DTPA cause serious effects in the biological treatment system, being more notorious with EDTA $^{58}$. EDTA is undesirable in biological treatment systems specially of those used to achieve metal removal, because the ligand prevents bacterial metal adsorption phenomenon ${ }^{62}$. These results have lead to the study of chemical treatment previous to the biological systems to increase the efficiency of this last one.

At laboratory scale, combined $\mathrm{UV} / \mathrm{H}_{2} \mathrm{O}_{2}$ treatment achieves rapid degradation in a synthetic TCF effluent ${ }^{63}$; just like the combined UV/ ozone treatment proved to be very efficient in the degradation of EDTA and DTPA chelates (98\%) degradation on synthetic TCF effluent ${ }^{64}$. The use of catalytic photooxidation processes to degrade EDTA is also currently being studied ${ }^{65-66}$, in which a semiconductor like $\mathrm{TiO}_{2}$ or iron doped $\mathrm{TiO}_{2}$ is used and activated by means of ultraviolet light. It has also been suggested that in order to treat large quantities of waste water, it would be economically more convenient to perform a pre-treatment combining ozone or $\mathrm{TiO}_{2}$ with the use of ionizing radiation (gamma rays) followed by a classic phase of biodegradation $^{68}$. The authors foresee that the main problems of the former techniques are energetic and economic, apart of achieving a complete toxicity assessment of the resulting by-products.

EDTA degradation has been attempted by diverse AOTs which has been extensively reviewed by Sillanpää and Pirkanniemi ${ }^{69}$. These technologies include: $\gamma$-radiolysis ${ }^{68}, \mathrm{TiO}_{2}$ photocatalysis ${ }^{66}, \mathrm{UV} / \mathrm{O}_{3}{ }^{64}$, $\mathrm{UV} / \mathrm{H}_{2} \mathrm{O}_{2}{ }^{53,64}$, solar ferrioxalate $/ \mathrm{H}_{2} \mathrm{O}_{2}{ }^{70}$, UV/electrochemical treatment $^{71}$, Fenton treatment $\mathrm{H}_{2} \mathrm{O}_{2} / \mathrm{Fe}(\mathrm{II})^{72}$, CAT-driven Fenton reaction ${ }^{73}, \mathrm{H}_{2} \mathrm{O}_{2}$ microwave-activated photochemical reactor treatment $^{74}$ among others.

\section{CONCLUSIONS}

In general, it can be seen that EDTA behaves as a persistent pollutant in the environment, enhancing the mobility and bioavailability of heavy metals. In natural environments studies detect poor bio-degradability of the ligand.

The interaction mechanisms of EDTA with living organisms are not sufficiently clarified and the range of their potential risks is not known. The studies that evaluate the toxicity of free heavy metals and complexed with EDTA do not enable the prediction of what the effect of the chelate presence will be. The effects of EDTA vary according to the type of organism studied, the concentration of EDTA and the metal analyzed.

There is an urgent need to investigate more on the bioaccumulation of heavy metals in the trophic chain promoted by EDTA and on the remobilization effect of metals in waters and soils. Studies on the potential risk of increased bioavailability of heavy metals by edible plant species exposed to metal-EDTA complexes are also missing.

The studies made so far, have focused, predominantly, on the evaluation of the bacterial ability to biodegrade EDTA at a laboratory scale, and it is to be noted that this property is extremely scarce in nature.

\section{ACKNOWLEDGEMENTS}

We thank FONDECYT Grant No 1010840 and to Dr. S. Valenzuela for the critical lecture of the manuscript. 


\section{REFERENCES}

1. Conway, M.; Holoman, S.; Jones, L.; Leenhouts, R.; Williamson, G.; Chem. Eng. 1999, 103, 86.

2. Williams, D.; Chem. Br. 1998, 1, 48.

3. Virtapohja, J.; Alén, R.; $10^{\text {th }}$ International Symposium on Wood and Pulping Chemistry, Yokohama, Japan, 1999.

4. Henneken, L.; Nörtemann, B.; Hempel, D.; Appl. Microbiol. Biotechnol. 1995, 44, 90 .

5. Nörtemann, B.; Appl. Microbiol. Biotechnol. 1999, 51, 751.

6. Pietsch, J.; Schmidt, W.; Sacher, F.; Fichtner, S.; Brauch, H.; Fresenius'J. Anal. Chem. 1995, 35, 75.

7. Sillanpää, M.; Rev. Environ. Contam. Toxicol. 1997, 132, 85.

8. Frank, R.; Rau, H.; Ecotoxicol. Environ. Saf. 1990, 19, 55.

9. Lo, K.; Yang, W.; Lin, Y. C.; Toxicol. Environ. Chem. 1992, $34,139$.

10. Friedly, J. C.; Kent, D. B.; Davis, J. A.; Environ. Sci. Technol. 2002, 36, 355.

11. Kent, D.; Davis, J.; Anderson, L.; Rea, B.; Coston, J.; Geochim. Cosmochim. Acta 2002, 66, 3017.

12. Means, J.; Crerar, D.; Science 1978, 200, 1477.

13. Palumbo, A.; Lee, S.; Boerman, P.; Appl. Biochem. Biotechnol. 1994, 45/ $46,811$.

14. Hakem, N.; Allen, P.; Sylwester, E.; Radioanal. Nucl. Chem. 2001, 250, 47.

15. Vassil, A.; Kapulnik, Y.; Raskin, Y.; Salt, D.; Plant Physiol. 1998, 117, 447.

16. Chen, H.; Cutright, T.; Chemosphere 2001, 45, 28.

17. Greman, S.; Velifonja-Bolta, D.; Vodnick, B.; Lestan, D.; Plant Soil 2001, 235,105

18. Sarret, G.; Vangronsveld, J.; Manceau, A.; Musso, M.; D’Haem, J.; Menthonnex, J.; Hazemann, J.; Environ. Sci. Technol. 2001, 35, 2854.

19. Dufková, V.; Arch. Hydrobiol. Suppl. 1984, 4, 479.

20. Hugenschmidt, S.; Planas-Bohne, F.; Taylor, D.; Arch. Toxicol. 1993, 67, 76.

21. Gabard, B.; Biochem. Pharmacol. 1974, 23, 901.

22. Heimbach, J.; Rieth, S.; Mohamedshah, F.; Slesinki, R.; Samuel-Fernando, P.; Sheehan, T.; Dickmann, R.; Borzelleca, J; Food Chem. Toxicol. 2000, 38, 99.

23. Wittaker, P.; Ali, S. F.; Imam, S. Z.; Dunkel, V. C.; Regul. Toxicol. Pharmacol. 2002, 18, 419.

24. Lanigan, R. S.; Yamarik, T. A.; Int. J. Toxicol. 2002, 21, 95.

25. Bergan, T.; Klaveness, J.; Aasen, A.; Chemotherapy 2001, 47, 10.

26. Hancock, R.; Annu. Rev. Microbiol. 1984, 38, 237.

27. Nikaido, H.; Vaara, M.; Microbiol. Rev. 1985, 49, 1

28. Tubbing, D.; Admiraal, W.; Cleven, R.; Iqbal, M.; Van de Meent, D.; Verweij, W.; Water Res. 1994, 28, 37.

29. Sillanpää, M.; Oikari, A.; Chemosphere 1996, 32, 1485

30. Sorvari, J.; Sillanpää, M.; Chemosphere 1996, 33, 1119.

31. Guilhermino, L.; Diamantino, T.; Ribeiro, R.; Goncalves, F.; Soares, A.; Ecotoxicol. Environ. Saf. 1997, 38, 292.

32. Kari, F.; Giger, W.; Environ. Sci. Technol. 1995, 29, 2814.

33. Nowack, B.; Environ. Sci. Technol. 2002, 36, 4009.

34. Kari, F.; Hilger, S.; Canonica, S.; Environ. Sci. Technol. 1995, 29, 1008.

35. Nowack, B.; Xue, H.; Sigg, L.; Environ. Sci. Technol. 1997, 31, 866.

36. Neale, C.; Bricka, R.; Chao, A.; Environ. Prog. 1997, 16, 274.

37. Papassiopi, N.; Tambouris, S.; Kontopoulos, A.; Water, Air, Soil Pollut. 1999, 109, 1.

38. Peters, R.; J. Hazard. Mater. 1999, 66, 151

39. Flemming, C.; Ferris, F.; Beveridge, T.; Bailey, G.; Appl. Environ. Microbiol. 1990, 56, 3191 .

40. Tiedje, J.; Appl. Microbiol. 1975, 30, 327.
41. Bolton Jr., H.; Li, S.; Workman, D.; Girvin, D.; J. Environ. Qual. 1993, $22,25$.

42. Allard, A.; Renberg, L.; Neilson, A.; Chemosphere 1996, 33, 577.

43. Madsen, E.; Alexander, M.; Appl. Environ. Microbiol. 1985, 50, 349.

44. Hinck, M. L.; Ferguson, J.; Puhaakka, J.; Proceedings of the $5^{\text {th }} I A W Q$ Symposium on Forest Industry Waste Waters, Vacouver-B.C., Canada, 1996.

45. Witschel, M.; Egli, T.; Zehnder, A.; Wehrli, E.; Spycher, M.; Microbiology 1999, $145,973$.

46. Bucheli-Witschel, M.; Egli, T.; FEMS Microbiol. Rev. 2001, 25, 69

47. Satroutdinov, A.; Dedyukhina, E.; Chistyakova, T.; Witschel, M.; Minkevich, E. V.; Egli, T.; Environ. Sci. Technol. 2000, 34, 1715.

48. Lauff, J.; Steele, D.; Coogan, L.; Breitfeller, J.; Appl. Environ. Microbiol. 1990, 56, 3346 .

49. Thomas, R.; Lawlor, K.; Bailey, M.; Macaskie, L.; Appl. Environ. Microbiol. 1998, 64, 1319.

50. Egli, T.; J. Biosci. Bioeng. 2001, 92, 89.

51. Gilbert, E.; Hoffmann-Glewe, S.; Water Res. 1990, 24, 39.

52. Sörensen, M.; Frimmel, F.; Z. Naturforsch. B: Chem. Sci. 1995, 50, 1845.

53. Sörensen, M.; Zureli, S.; Frimmel, F.; Acta Hydrochim. Hydrobiol. 1998, 26, 109.

54. Kari, F.; Giger W.; Water Res. 1996, 30, 122

55. Nirel, P. M.; Pardo, P. E.; Landry, J. C.; Revaclier, R.; Water Res. 1998 , 12,3615 .

56. Saunamäki, R.; Tappi J. 1995, 78, 185

57. Sillanpää, M.; Chemosphere 1996, 33, 293.

58. Mutis, A.; Freer, J.; Baeza, J.; Rodríguez, J.; Proceedings of the $7^{\text {th }}$ International Conference on Biotechnology in the pulp and paper industry, Vancouver-BC, Canada, 1998

59. Virtapohja, J.; Alén, R.; Pulp Paper-Canada 1998, 99, 53.

60. Van Ginkel, C.; Virtapohja, J.; Steyaert, J.; Alén, R.; Tappi J. 1999, 82, 138.

61. Kaluza, U.; Klingelhöfer, P.; Taeger, K.; Water Res. 1998, 32, 2843.

62. Hafez, M. B.; Fouad, A.; El-Desouky, W.; J. Radioanal. Nucl. Chem. 2002, $251,249$.

63. Baeza, C.; Zaror, C.; Freer, J.; Baeza, J.; Rodríguez, J.; Proceedings of the $2^{\text {nd }}$ International Conference on Oxidation Technologies for Water and Waste Water Treatment, Clausthal-Zellerferd, Germany, 2000.

64. Rodríguez, J.; Mutis, A.; Yeber, M. C.; Freer, J.; Baeza, J.; Mansilla, H.; Water Sci. Technol. 1999, 40, 267.

65. Madden, T.; Datye, A.; Fulton, M.; Prairie, M.; Majumdar, S.; Stange, B.; Environ. Sci. Technol. 1997, 31, 3475.

66. Davis, A. P.; Green, D. L.; Environ. Sci. Technol. 1999, 33, 609.

67. Navío, J.; Testa, J.; Djedjeian, P.; Padrón, J.; Rodríguez, D.; Litter, M.; Appl. Catal., A 1999, 178, 191.

68. Krapfenbauer, K.; Getoff, N.; Radiat. Phys. Chem. 1999, 55, 385

69. Sillanpää, M.; Pirkanniemi, K.; Environ. Technol. 2001, 22, 791.

70. Emilio, C. A.; Jardim, W. F.; Litter, M. I.; Mansilla, H. D.; J. Photochem. Photobiol. 2002, 151, 121.

71. Chaudhary, A.; Donaldson, J.; Grimes, S.; Hassan, M.; Spencer, R.; J. Chem. Technol. Biotechnol. 2000, 75, 358

72. Mochidzuki, K.; Takeuchi, Y.; Sep. Purif. Technol. 1999, 17, 125.

73. Oviedo, C.; Contreras, D.; Freer, J.; Rodríguez, J.; Fresenius' Environ. Bull. in press.

74. Kunz, A.; Peralta-Zamora, P.; Durán, N.; Adv. Environ. Res. 2002, 7, 197.

75. Loyaux-Lawniczak, S.; Douch, J.; Behra, P.; Fresenius' J. Anal. Chem. 1999, 364, 727.

76. Belly, R. T.; Lauff, J. J.; Goodhue, C. T.; Appl. Microbiol. 1975, 29, 787.

77. Henneken, L.; Nörtemann, B.; Hempel, D.; J. Chem. Technol. Biotechnol. 1998, 73,144 . 